\title{
テクノスケープ・リノベーションの意味論的研究
}

\section{Study on Meaning of Technoscape Renovation}

\author{
岡田 昌彰* \\ Masaaki OKADA
}

\begin{abstract}
Recently, renovation project of existing structures, such as old architecture, industrial or civil engineering facilities are taken for efficient use of existing facilities with different functions. This current on social facilities may suggest the gradual change of value from flow (scrap and build) to social "stock". Their purposes of renovation are to acquire economic benefit or efficient preservation of cultural heritages, however, landscape or spatial values or meaning of renovated landscape or space which the structures take on as a result of renovation have yet to be sufficiently discussed.

This study reviews social trend of renovation projects, and introduction of existing aesthetic theory of Mitate and Estrangement permits the manifestation of potential value of landscape and space, such as significance of "distance" caused by semantic difference between present and past use. In this meaning, landscape and space of industrial or civil engineering facilities (i.e. technoscape and technospace), such as watertowers, channel defenses, or abolished railway tracks are concluded to possess high potential to produce estranged value when renovated.
\end{abstract}

Keywords: Technoscape, Renovation, Mitate, Landscape, Stock キーワード：テクノスケープ，リノベーション，見立て，景観，ストック

\section{1. 研究の背景と目的}

既存の建造物に新たな機能を与えて用途転用し，ハードを有効 に活用しようという「リノベーション維(1)」が内外で実施されて いる。欧米に扔いても歴史的建造物の用途転用が盛んに行われて いるほか，わが国では 1990 年代後半より急速に注目を集めはじ め, 廃業した銀行や小学校の建築がブティックやレストラン, 地 域センターなどに転用されるケースが見られる。

リノベーションの意義として「既存施設の再活性化」「文化的 ストック蓄積の機会の提供」3)「ふるさと資源の積極的活用 $\rfloor^{4)}$ な どが指摘されているほか，新築に比べ経済的であるケースがある 点も近年注目されている ${ }^{5)}$ 。また, 建築界においては新たな創造 の手法としても注目されている。大江は建築保存手法として (1) 守る保存 及び(2)攻める保存 の 2 種を挙げ, 前者が単なる原 型保存であるのに対し後者（リノベーション）を内部プログラム の変更による「再生」手段として位置づけている袮住(2)。

\section{曰芸術空間 曰飲食施設 曰商業施設 ロ宿泊施設 ロその他(住宅·オフィス等)}

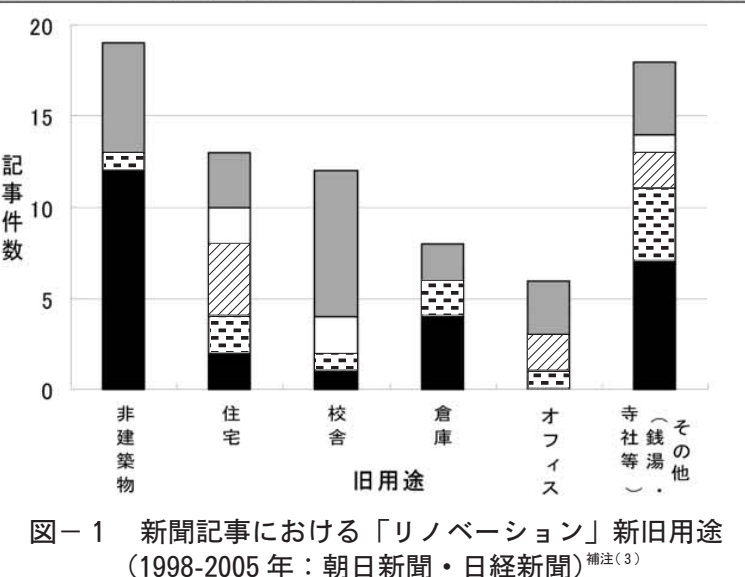

いっぽう，新聞記事などメディアでも多く取り上げられており， 各事例がその経緯や意義とともに紹介されている（図－1）。用 途転用対象は校舎や倉庫などの建築物から，廃坑やトンネル，鉄 道ガード下などの非建築物にまで及んでおり, 特に後者は美術館 など芸術的空間に多く転用されているのがわかる。そのほか，リ ノベーション建築そのものの探訪・紹介文献も出版されるな (゙'1)4，現在は広く人口に膾采しつつある概念であると言える。

しかし，用途転用された結果生じる景観・空間の美学的意義な ど潜在的可能性については十全たる議論は展開されていない。家 倉ら ${ }^{7}$ は転用された近代建築空間の特質について，訪問者の記述 をもとに明らかにするも産業施設や土木構造物など非建築物を対 象とした景観・空間の意義については言及するには至っていない。 岡田 ${ }^{8)}$ は産業施設のストック的活用策としてリノベーションの意 義を提示し，用途転用施設の呈するテクノスケープの意義につい て言及しているが，その論理的考察には至っていない。

本研究は，再利用されたテクノスケープとその空間に着目し， 「見立て」をはじめ既存美学における価值体系を導入することで, 景観・空間の潜在的価值を明確化することを目的とする。

本研究では特に, 既存用途に対し新たな機能が付与されること により, 用途転用された構造物や建築物が特有の美学的特性を獲 得し得る点に着目する。すなわち, 大江 ${ }^{6)}$ が指摘しているように, そこには旧用途・新用途といった 2 種の異なる性格をもつ景観・ 空間構成要素が共存・対峙することとなる。このように, 性格の 異なる二元の対峙による景観価值については, 既往研究で “景観 異化” 発現の指摘とともに明らかにされているが ${ }^{9}$ ， 二元対峙の パターンとして表一 1 のような 3 種のケースがあるものと考えら れる。例えば，自然石と人工的なコンクリート製の台座を対置さ せることによって「自然一人工」の対峙による美学を創出した Michael Heizer の作品に見られるような「並置」による対峙, 旧ガスプラントの周辺を既存のコンテクストとは全く異なる芝生 によって覆わせた Gasworks Park に見られるような「包含」の 
表一 1 二元対峙の生起形態

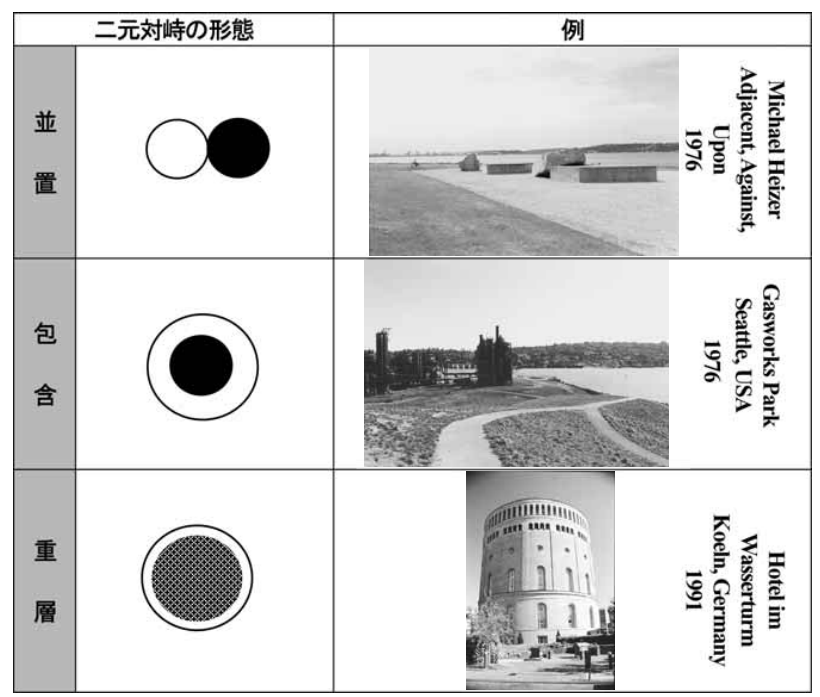

対峙，および給水塔をホテルに改装した Hotel im Wassertuem のように，二元がオーバーラップして共存することによる「重層」 の対峙 として整理できる。特に水の貯蔵やガス格納といった元 来人間の居住や活動から乘離したシステムによって構成されるテ クノスケープ（あるいは，テクノスペース）に建築的・遊戯的用 途が事後的に加わることによって, 前後のコードの差異は顕著な ものとなる。本研究ではまず, 日本の古典における「見立て」の 美学と服飾デザインにおける転用の美学を整理する。さらにこの ような美学的特長を顕著に示すリノベーション事例を挙げ, それ ぞれの形成景観や内部空間を現地調査することにより, 二元対峙 の創出項目として旧用途の痕跡を抽出し新用途との距離感を議論 することによって多義性生成の可能性を検討する。

\section{2. リノベーション空間の美学的意義}

\section{（1）日本の古典における「見立て」の美学}

「見立て」とは，和歌・俳諧などである物を別のものと仮にな ぞらえて表現することによる美学創出の手法を意味する。これに ついて山口昌男は, 類似箇所を残しながら形を全て変えることに よって創出される「距離感」䑾(4) の重要性を指摘している ${ }^{10)}$ 。さら に山口は「多義的な面白さを作り出す手法」としての見立ての可 能性を指摘し,「異化」踈注(5) との概念的類似性を指摘しているほか, 青木孝夫 ${ }^{13)}$ は元の文脈と新たな文脈の 2 視点が反映・交錯・照応 することにより「見立ての美学」が成立するとしている。

例えば，山㠃宗鑑の連歌「月に柄をさしたらばよき団扇かな」 は, “柄を挿された月”之団扇の「丸と線の輪郭」という共通点 を残しながら，俗世界と宇宙という大きな距離感の強調により， 詩情の創出を実現している例といえる（図－2）。

いっぽう, 広重による「即興陰ぼし尽し」は江戸時代の酒宴の 席で余興に演ずる遊びの手本として描かれた浮世絵であるが（図一 3 )，いずれも「石燈篭」「根上がりの松」「鷹に止まり木」といっ た影絵が雅趣に富む表題とともに表現されている。しかし意外に も, これらの雅趣に富む影絵は背後で余興に興ずる江戸庶民によっ て身振りで演じられている。ここにも, 同一のシルエットを共有 しながらも, 影絵における想像上の雅趣と, それとは対照的な俗 的な酒客の身振りとの間に「距離感」を創出することで, 特有の 味わいの表現を実現しているものといえる穞注(6)。

\section{（2）現代服飾デザインにおける転用の美学}

いっぽう, 現代の服飾デザインにおいても見立てに共通する手 法が見られる。服飾史家・中野香織15) は, コインや紙幣などの対 象に「本来の用途にない用い方」を施すことによる潚酒の演出法

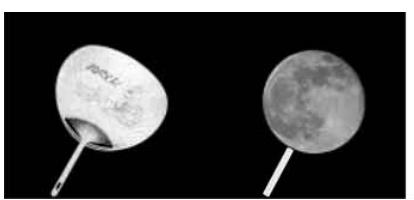

図一 2 俗世界と宇宙の距離 感による「見立て」の創出例
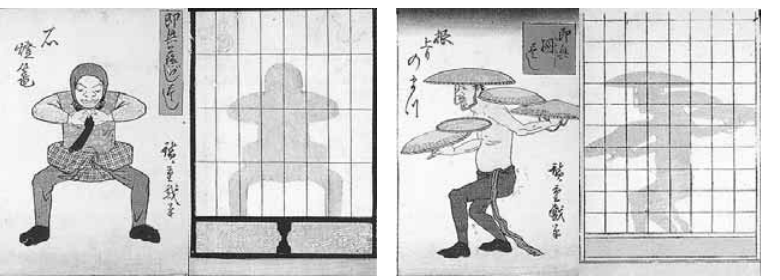

図-3 広重「即興陰ぼし尽し」(江戸時代) 「石燈篭」及び「根上がりの松」

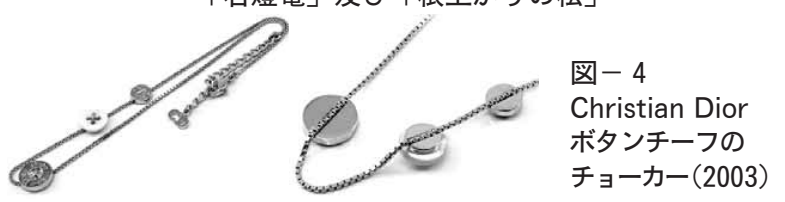

を指摘している。例えば, Christian Dior が 2003 年に発表した ボタンモチーフのチョーカーなどはその典型例と言え，“衣服を 打ち合わせてとめる”というボタンの機能を転用によって捨象し その外形のみを純粋な造形要素として取り入れた作品と捉えるこ とができよう（図－4）。

\section{3. テクノスケープ・リノベーションの可能性}

次に, 産業施設や土木構造物など非建築物や空間のリノベーショ ン事例を挙げ， 2 種の異なるコードとしての前後用途の重層的共 存による空間的特質の生起に着目し, テクノスケープ・リノベー ションの可能性として提示すこととする。

（1）送水井：相模原市老人福祉センター・渓松園（図-5・6） 神奈川県相模原市の「老人福祉センター溪松園」は, 横浜水道 の導水勾配上昇による導水能力の向上を目的として整備された 「大島送水井」(1934 年竣工) を 1972 年に老人ホームに転用した 施設である。1972 年当時はリノベーションの意義に対する議論 は盛んではなかったが, 送水井廃止によって遊休化していた八ー ドの効率的な活用を意図し転用するに至っている ${ }^{17}$ 。

有蓋建造物であることが新旧用途の共通形態であるが，送水機 能によって生起した円形平面形状の上に放射状の壁による部屋割 が重層的に施され，部屋の入口から奥に向かって末広がりの扇形 平面が現出しており稙注( )，各部屋に敷かれた畳は扇形の中心角に 合わせて斜めに切断されている。送水機能と, 娛楽, 読書, 健康 相談といった老人福祉関連の諸活動とのイメージ的距離感によっ て特徵的な空間が生成しているといえる。

\section{（2）配水塔：名古屋市演劇練習館（図－7）}

配水塔は一般に $20 \mathrm{~m}$ 前後の高さを有することによって地域の ランドマークとしての地元住民の愛着を獲得するケースが少なく ない䚭(8)。名古屋市西部地区の上水道供給を目的として 1937 年 に竣功した旧稲葉地配水塔は, 約 $30 \mathrm{~m}$ の高さとともに道路と一 体的な空間処理がなされ ${ }^{18}, 1989$ 年の名古屋市都市景観重要建造 物指定を経て 1992 年に演劇練習館に転用されている。

この事例においても有蓋建造物であることが新旧用途の共通形 態であるが，配水機能により現出した円形平面に重層的に扇形の 部屋割や円形の吹き抜け空間が生起しているほか, 旧用途を示す 配水管が保存展示されている。ここでも, 配水機能と演劇活動と のイメージ的距離感によって特徵的な空間が生成している。

（3）要塞：和歌山市少年自然の家 (図-8)

旧要塞には近年土木学会選奨土木遺産に認定されているものも あり稓注 (9) , このような近代土木遺産などの機能的空間を用途転用 
する事例屯近年数多く見られる。和歌山市加太地区の「和歌山市 立少年自然の家」は，1906 年に竣工し戦後廃止された旧加太田 倉崎砲台跡を利用し 1974 年に整備された。半地下交通路や斜堤, 砲座など，相手に発見されることなくかつ相手の位置を死角なく

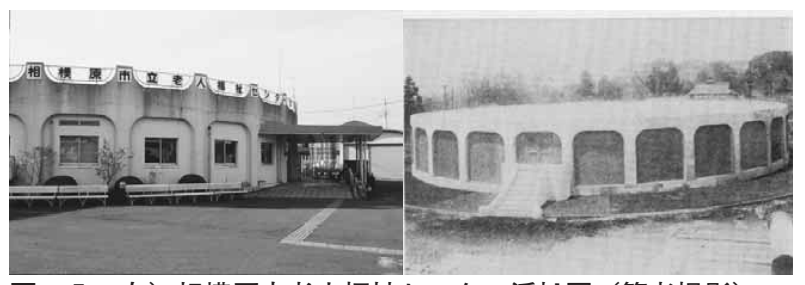

図－5 左）相模原市老人福祉センター渓松園（筆者撮影）
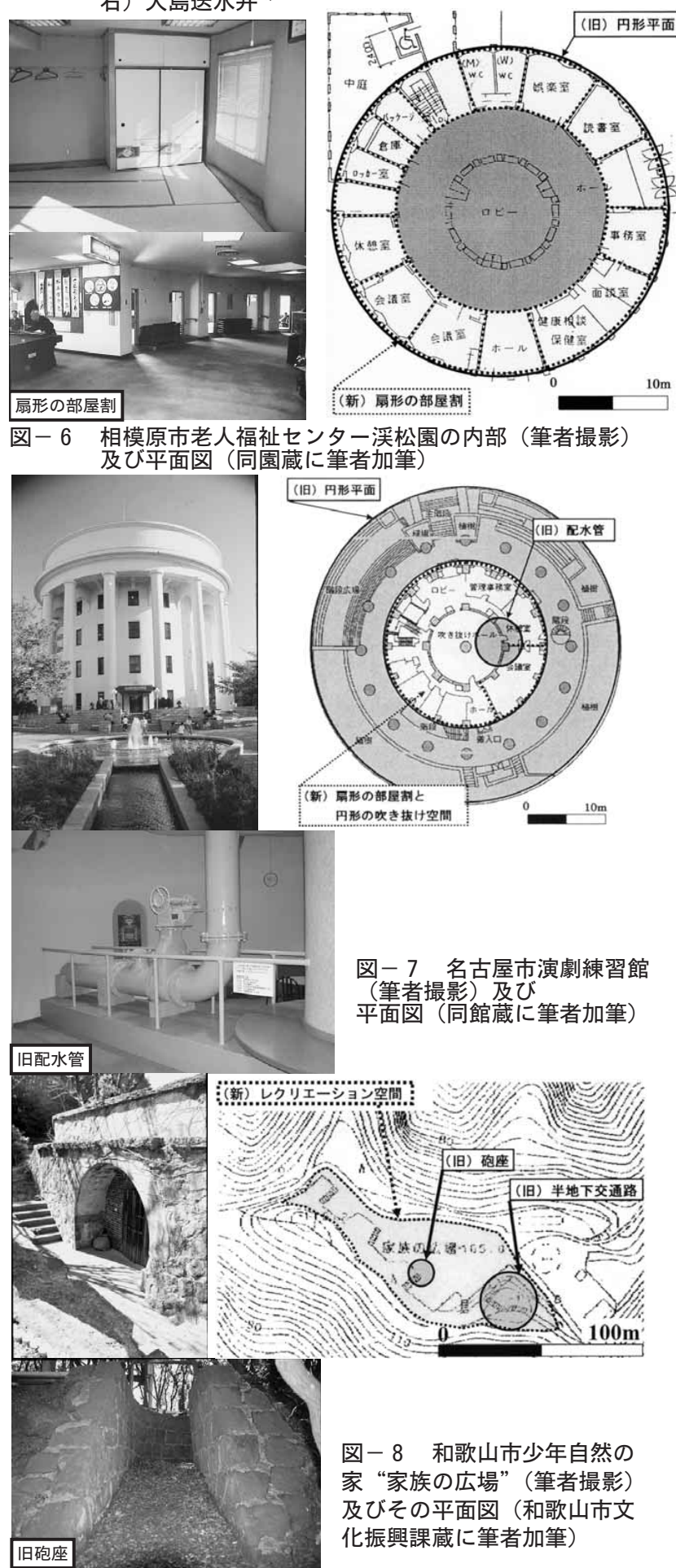
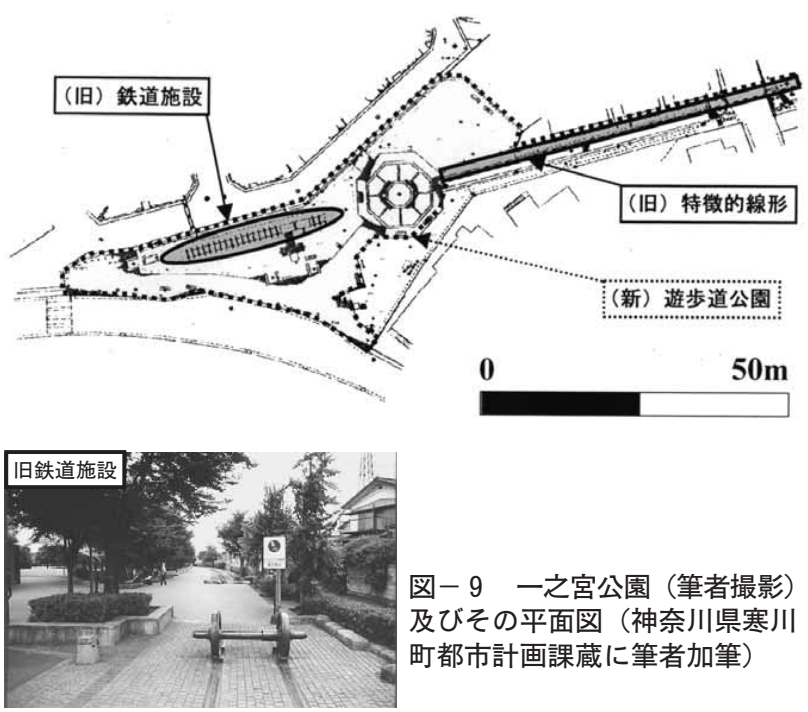

見定める工夫が施されたいわば国防目的の「眺望一隠れ場的空間」 が生起している。現在はこの空間を活用した昆虫観察や肝試し探 検などができる「家族の広場」が整備されている絉社(10)。

特に肝試し探検には「眺望一隠れ場」的感覚が伴うと考えられ, この性質が新旧両用途の共通形態として位置づけられる。旧国防 空間に現代的レクリエーション空間が重層しており，さらに“国 防”と“レクリエーション”とのイメージ的距離感によって空間 の特長が引き出されていると考えられる解注(11)。

（4）鉄道廃線跡：一之宮公園（図一-9）

近年，社会的注目を集めている鉄道廃線跡緗注(12) が，自転車道や 遊歩道に転用される事例が見られる。神奈川県寒川町の一之宮公 園・緑道は，旧国鉄相模線西寒川支線跡地紸 $(13)$ が，旧用途の記憶 を地域に留めるべく 1986 年に緑道公園として整備されたもので ある ${ }^{23)}$ 。園内には $100 \mathrm{~m}$ ほどの軌道と「車止め」に転用された車 輪が保存され，軌道跡はそのまま緑道として整備されている。

線的空間であることが新旧用途の共通形態であるが，軌道機能 によって現出した特徽的な曲率半径献注(1) や旧鉄道施設の展示を伴 いながら緑道が重層的に施されている。軌道や車輪の展示により, 鉄道空間と遊歩空間とのイメージ的距離感がさらに強調され特徴 的な空間が生成しているといえる。

（5）４事例における生成空間の特徵のまとめ（表－2）

いずれの事例においても，残存施設や空間形態などによって旧 用途の形態が明快に継承され，そこに新たな用途が重層的に共存 している。“見立て”の前提となる新旧用途の「共通点」は，溪 松園と演劇練習館においては有蓋構造物として，また非建築物の 砲台跡と廃線跡においてはそれぞれ眺望一隠れ場的空間や線的空 間形状に扔いて実現している。一方，両者の「距離感」は「送配 水，鉄道輸送，国防」といった人間超越的な旧機能と，遊戯・遊 歩・市民交流といったヒューマンな新用途との間のイメージ的距 離感のほか，旧機能が明快に反映された空間や旧施設に対するパ ブリックアクセスの供与が旧用途を強調し, “距離感”の創出を 助長しているものと考えられる。

4 事例は旧用途のほかスケールや立地条件なども異なるため, より多くの事例精査に加え訪問者の創造イメージを調査・類型化 した上で多義性生成を検証する必要があるが, 例えば演劇練習館 と一之宮公園については既存空間の記憶継承を前提とした景観・ 空間整備が意図されていることから, 立地地域の原風景としての 旧施設への愛着が既存の意味として存在するものと考えられる。 また，各事例において特徴的空間に展開するアクティビティの多 様性など，さまざまな意味の生成が実現していると考えられる。 


\section{表 $-2 \quad 4$ 事例の総括}

\begin{tabular}{|c|c|c|c|c|}
\hline & 明用途 & $\begin{array}{l}\text { 旧用途の形熋 } \\
\text { 新用途の形態 }\end{array}$ & $\begin{array}{c}\text { 新旧用途の } \\
\text { 共通形態 }\end{array}$ & 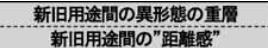 \\
\hline \multirow{2}{*}{1} & 大島送水井 & 円形の平面形状 & \multirow{2}{*}{$\begin{array}{l}\text { 有蓋 } \\
\text { 建物 }\end{array}$} & 送水形状（円形）の部屋割 \\
\hline & $\begin{array}{c}\text { 老人福祉センタ- } \\
\text { 渓松園 }\end{array}$ & 啺形の部屋割 & & $\begin{array}{l}\text { 送水機能と福社活動との } \\
\text { イメージ的な距離感 }\end{array}$ \\
\hline \multirow{2}{*}{2} & $\begin{array}{l}\text { 稲葉地 } \\
\text { 配水塔 }\end{array}$ & $\begin{array}{l}\text { 円形の平面形状 } \\
\text { 配水管の展示 }\end{array}$ & \multirow{2}{*}{$\begin{array}{l}\text { 有蓋 } \\
\text { 建牿物 }\end{array}$} & 配水機能（円形）の部屋割 \\
\hline & $\begin{array}{l}\text { 名古屋市 } \\
\text { 演频練習館 }\end{array}$ & $\begin{array}{l}\text { 扇形の部屋割と } \\
\text { 円形の吹抜空閥 }\end{array}$ & & $\begin{array}{l}\text { 配水機能と演劇活動との } \\
\text { イメージ的な距㠛感 }\end{array}$ \\
\hline \multirow{2}{*}{3} & $\begin{array}{l}\text { 加太田倉崎 } \\
\text { 砲台 }\end{array}$ & $\begin{array}{l}\text { 半地下交通路 } \\
\text { 斜堤・砲座 }\end{array}$ & \multirow{2}{*}{ 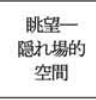 } & $\begin{array}{l}\text { 旧国防的空開におけるレクリエー } \\
\text { ション }\end{array}$ \\
\hline & $\begin{array}{l}\text { 和歌山市 } \\
\text { 少年自然の家 }\end{array}$ & 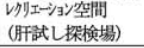 & & $\begin{array}{l}\text { 国防とレクリエーション用途との } \\
\text { イメージ的な距踓感 }\end{array}$ \\
\hline \multirow{2}{*}{4} & $\begin{array}{c}\text { 相模線 } \\
\text { 西寒川支線 }\end{array}$ & $\begin{array}{l}\text { 特徽的線形 } \\
\text { 旧鉄道施設展示 }\end{array}$ & \multirow{2}{*}{$\begin{array}{l}\text { 線的空間 } \\
\text { (道空間) }\end{array}$} & $\begin{array}{l}\text { 曲率の大きな旧鉄道軗地の遊歩道 } \\
\text { 空間 }\end{array}$ \\
\hline & $\begin{array}{l}\text { 寒川町 } \\
\text { 一之宮公園 }\end{array}$ & 遊步道公園 & & $\begin{array}{l}\text { 鉄道空間と遊歩空間との } \\
\text { イメージ的な距睢感 }\end{array}$ \\
\hline
\end{tabular}

\section{4. 結語}

本研究は, 工業施設や土木構造物のリノベーション景観・空間 について,「見立て」の美学の援用によりその可能性を明らかに し, さらに「距離感創出」という観点におけるテクノスケープの 有為性を事例とともに潜在的価值として提示した。

現在の近代化遺産利活用における議論は主に経済性やまちおこ しといった観点を中心に展開されているが, 用途転用の結果創出 される景観・空間の価值を意図的に引き立たせるような景観計画 や創出空間の活用策を検討することが今後の課題となる。

\section{補注}

（1）リノベーション（Renovation）は「刷新」「修䌜」「回復」などを意 味するが，建築界では「既存の建築を有効に再利用し，増改筑すること で以前とは別の用途として機能させる再生手法」とされている11。また, 国土交通省都市地域整備局により大都市空間の修復・更新・有効活用を 目的として 2000 年に策定された「東京圈のリノベーション・プログラ ム」²1等に見られるように, この用語には個別の建造物のみならず都市 や空間も刘象とする概念が含まれるため, 構造物の景観あるいは空間全 体を対象とする本研究における援用概念にも合致する。従って本論文で は，主に建物の異種用途への変更（転換）を意味する「コンバージョン」 などの類語に優先させ「リノベーション」を用いることとした。

（2）大江は，「攻める保存」に扔いて「2つの時感が互いの異質性を認め ながら共生する」，すなわち既存 VS 新築の系が重㸚合わされることに その特性の 1 つを見出している。

（3）各施設の新旧両用途が明確に言及されている記事を抽出した。

（4）鈴木廣之は，二重構造の二者の連絡を確実に保たせる「類似の発見」 が存在した上で, 両者の距離は「できるだけ相違していたほうが面白い 見立て」となる点を指摘している111。

（5）異種コードの対立による重層的意味作用によって「曖昧さ」が生じ, それによって「異化」の美学が創出されるとされており ${ }^{12}$, これも重層 的な二元対峙の構造として捉えることができる。

(6) 身振り之影絵の関係について, 稲垣 ${ }^{14)}$ は「ポジとネガ」を例示し, 身 振りの中から平面的なシルエットの正体を知る面白さの発見をその本質 の 1 つとして指摘している。

（7）本館地下は行政関連の書庫となっているが, 各書棚が円形平面に放射 状に配置されており，書棚に施されたラベルを検索する上では効率がよ いという ${ }^{17)}$ 。

（8）例えば東京都の駒沢配水塔, 高岡市の水道公園配水塔などがあるほか, ドイッ・マンハイム市, 米国・シカゴ市などのように, 町のランドマー クとなった配水塔を観光資源として利活用する事例も見られる。

（9）土木学会選奨土木遺産となった要塞施設として, 猿島要塞 (2000), 芸予要塞小島砲台跡（2001），友ヶ島砲台群（2002）がある。
（10）安全対策は十分に行われており，回遊筒所も限定されている ${ }^{19}$ 。

（11）国防なる機能がリアリティを希薄化させた現代において，旧用途の 認識がきわめて困難となり, 国防空間が元来もっていた意味に比してそ の空間的特徴が強く認識されるという考え方もできる。沿岸域要塞に対 する訪問者のこのような空間特性評価については先行研究20) で明らかに されている。また，「眺望一隠れ場」が動物行動学的な空間的性質 24 で あることは特徵的であり, 国防そのものの具体的なイメージ認知と空間 特性との関係については今後検討する必要がある。

（12）例えば，宮脇俊三（1995-2003）：鉄道廃線跡を歩く 1 10：JTB キャ ンブックスなどが刊行されている。

（13）相模川の砂利輸送を目的として 1922 年に開通した全長 $1.9 \mathrm{~km}$ の支線 で，1984 年に廃止となった。

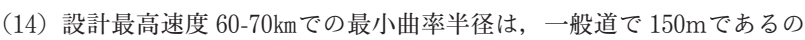
に対し, J R 在来線では $300 \mathrm{~m}$ とっている ${ }^{22}$ 。なお，鉄道空間として の特徵には建築限界や縦断線形なども挙げられるが，詳細な分析につい ては今後の発展的研究において議論することとしたい。

\section{参考文献}

1) 高木伸哉ほかフリックスタジオ（2001）：東京リノベーション：廣済 堂

2 ）現代用語の基礎知識 2005, 自由国民社

3 ）五十嵐太郎ほか (2003)：リノベーション・スタディーズ〜第三の方 法：INAX 出版, p.7

4 ）自治大臣官房地域政策室監修（1990）：再発見ふるさと資源\&ランド マーク，ぎょうせい：わが国に扔ける初期の用途転用事例集と言える。

5 ）建築家・中谷ノボル氏は新築マンションに比較したリノベーションの 経済性を提唱している。(朝日新聞 2004 年 6 月 8 日号)

6 ) 大江匡 (1994)：創造行為としての保存・再生：建築設計資料 45 保存 再生，建築資料研究社，95-97

7 ) 家倉敬和・岡田昌彰（2004）：近代建築におけるリノベーション空間 の特性に関する研究：日本都市計画学会関西支部講演集 2

8 ) 岡田昌彰 (2004)：ストックとしてのテクノスケープ：ランドスケー プ研究 68(1)

9 ）岡田昌彰・堀繁（2003）：テクノスケープ・レトリック論としての二 元対峙景観に関する研究：ランドスケープ研究 66(5)

10）山口昌男・高階秀爾（1996）：「見立て」と日本文化：日本の美学 24 , ペりかん社, 4-23

11）鈴木廣之（1996）：類似の発見：日本の美学 24，ペりかん社，82-101

12）池上 嘉彦(1984)：記号論への招待：岩波新書

13）青木孝夫（1996）：＜見立て>の美学：日本の美学 24 , ペりかん社, 36-62

14）稲垣進一（1988）：江戸の遊び絵 : 東京書籍, 154-155

15）中野香織（2005）：転用の美学：モードの方程式, 日本経済新聞 2005 年 7 月 1 日号

16）横浜市水道局（1987）：横浜水道百年の歩み

17）渓松園へのヒアリングによる（2003 年 1 月実施）

18）田中良英・岡田昌彰（2005）：名古屋市演劇練習館（旧稲葉地配水塔） の景観・空間特性に関する研究 : 土木計画学研究・講演集 Vol.32

19）自然の家へのヒアリングによる（2005 年 10 月・2006 年 1 月実施）。

20）岡田昌彰（2004）：旧沿岸域要塞における景観・空間の価值評価に関 する研究：土木学会海洋開発論文集第 20 巻

21）例えば，国土交通省都市・地域整備局 HP：http://www.mlit.go.jp/ crd/daisei/tokyo_renovation/（2006 年 1 月現在）

22）森島宗太郎（1977）：鉄道工学：森北出版

23）寒川町都市計画課へのヒアリングによる（2006 年 1 月実施）。

24）ジェイ.アプルトン（菅野訳）（2005）：風景の経験：法政大学出版局 